\title{
ANALISIS PENGARUH KOMPENSASI TERHADAP KEPUASAN KERJA KARYAWAN PADA CV. SETIA BUDI DI BANDAR LAMPUNG
}

\author{
Dede Bastian ${ }^{(1)}$, Kuswarak $^{(2)}$, Khairul Saleh ${ }^{(3)}$ \\ Fakultas Ekonomi Universitas Sang Bumi Ruwa Jurai \\ dede.bastian21@gmail.com, kuswarak@fe.saburai.ac.id, khairul.saleh@fe.saburai.ac.id
}

\begin{abstract}
Abstrak. Kompensasi sangat mempengaruhi kinerja pegawai, jika kompensasi yang diberikan oleh dinas/satker sesuai dengan pekerjaan yang dikerjakan oleh pegawai, maka kinerja pegawai dapat meningkat. Kepuasan kerja (job satisfaction) adalah keadaan emosional yang menyenangkan atau tidak menyenangkan dengan mana para pegawai memandang pekerjaan mereka. Tujuan dari penelitian Untuk mengetahui Pengaruh Kompensasi Terhadap Kepuasan kerja Pada CV. Setia Budi. Hasil pengujian bahwa nilai $R$ square sebesar 0.196. Nilai $R$ square ini menunjukkan bahwa besarnya kontribusi variabel independen terhadap variabel dependen adalah sebesar 19,6\%, sedangkan sisanya sebesar 80,4\% ditentukan oleh variabel lain yang tidak teridentifikasi dalam penelitian ini. Hipotesis yang menyatakan "Kompensasi berpengaruh terhadap kepuasan kerja." Pengujian dilakukan dengan menggunakan uji t yang menunjukkan bahwa Kompensasi berpengaruh terhadap kepuasan kerja. Pengujian dilakukan dengan menggunakan uji t pada tingkat keyakinan signifikansi $\alpha 0.05$, tingkat signifikansi sebesar $0.03<0.05$ dengan nilai $\mathrm{t}_{\text {hitung }}>\mathrm{t}_{\text {tabel }}$ yaitu $2.314>2.0686$, dengan demikian hipotesis diterima yang berarti modal kompensasi berpengaruh terhadap kepuasan kerja.
\end{abstract}

Kata kunci: Kepuasan, Kompensasi, Kerja, Pengaruh.

\section{PENDAHULUAN}

Sumberdaya manusia merupakan aset yang dapat meningkatkan keberhasilan organisasi. Kemampuan sumberdaya manusia merupakan kunci utama untuk mampu menghadapi persaingan dalam era globalisasi, kemampuan ini sering disebut keunggulan kompetitif. Paradigma baru dalam pengelolaan kegiatan organisasi adalah pendayagunaan sumberdaya manusia. Hal tersebut di cerminkan dari peran sumberdaya manusia dalam kegiatan organisasi.

Kepuasan kerja (job satisfaction) adalah keadaan emosional yang menyenangkan atau tidak menyenangkan dengan mana para karyawan memandang pekerjaan mereka. Kepuasan kerja mencerminkan perasaan seseorang terhadap pekerjaannya. Ini nampak dalam sikap positif karyawan terhadap pekerjaan dan segala sesuatu yang dihadapi di lingkungan kerjanya. Keith Davis dalam Mangkunegara Prabu AA Anwar mengemukakan bahwa, "job satisfaction is the favorableness or unfavorableness with employees view their work" atau kepuasan kerja adalah perasaan menyokong atau tidak menyokong yang dialami pegawai dalam bekerja (Mangkunegara, 2014). Dari pendapat tersebut perasaan yang berhubungan dengan pekerjaan melibatkan aspek-aspek seperti upah atau gaji yang diterima, kesempatan pengembangan karir, hubungan dengan pegawai lainnya, penempatan kerja, jenis pekerjaan, struktur organisasi, mutu pengawasan.

Konsekuensi dari kepuasan kerja, Seperti sudah dijelaskan pada bagian sebelumnya mengenai kepuasan kerja, maka beberapa konsekuensi kepuasan kerja dapat dirangkum sebagai berikut : Kepuasan dan Motivasi, Suatu penelitian 
meta analisis yang dilakukan oleh A J Kinicki, dkk dalam Mangkunegara Prabu AA Anwar (2010) meliputi 9 hasil analisis yang melibatkan 2.237 orang pekerja mengungkapkan ada hubungan yang positif dan signifikan antara motivasi dan kepuasan kerja.

Karena kepuasan dengan pengawasan berkorelasi secara signifikan dengan motivasi, para manager disarnkan untuk mempertimbangkan bagaimana perilaku mereka mempengaruhi kepuasan kerja. Para manager secara potensial meningkatkan motivasi para karyawan melalui berbagai usaha untuk meningkatkan kepuasan kerja. Kepuasan dan Keterlibatan dalam Pekerjaan, Keterlibatan dalam pekerjaan merupakan keterlibatan individu dengan peran dalam pekerjaannya.

Robbins dalam Sunyoto (2010) menjelaskan bahwa adalah logis menganggap kepuasan sebagai predictor utama, karena karyawan yang puas cenderung akan berbicara positif mengenai organisais, membantu individu lain, dan melewati harapan normal dalam pekerjaan mereka. Selain itu, pegawai yang puas mungkin akan memberikan peran yang lebih karena merespon pengalaman positif mereka., Kepuasan kerja dengan Komitmen Organisasi, Komitmen organisasi mencerminkan bagaimana individu mengidentifikasikan dirinya dengan organisasi dan terikat dengan tujuantujuannya. Para manager disarankan untuk meningkatkan kepuasan kerja dengan tujuan mendapatkan tingkat komitmen yang lebih tinggi. Selanjutnya komitmen yang tinggi dapat mempermudah terwujudnya produktivitas yang lebih tinggi (Matheu dan Zajac, dalam Hasibuan 2010).

Kompensasi sangat mempengaruhi kinerja pegawai, jika kompensasi yang diberikan oleh perusahaan sesuai dengan pekerjaan yang dikerjakan oleh pegawai, maka kinerja pegawai dapat meningkat. Menurut Husein Umar dalam Sunyoto
(2012) menyatakan bahwa salah satu cara manajemen untuk meningkatkan kinerja para pegawai adalah melalui kompensasi. Kompensasi di definisikan sebagai sesuatu yang di terima oleh pegawai sebagai balas jasa untuk jasa mereka.

Kinerja dianggap sesuatu yang penting, baik bagi organisasi maupun bagi pegawai itu sendiri. Hal ini dikarenakan apabila kinerja dari pegawai meningkat atau relatif bagus, maka pegawai itu sendiri akan mendapatkan kompensasi atau balas jasa yang setimpal dengan kinerja dari pegawai tersebut. Tentu saja kegiatan-kegiatan dapat diselesaikan tepat waktu dan tujuan dapat dicapai dengan baik. Apabila seorang pegawai menganggap bahwa kompensasi yang diberikan oleh perusahaan sesuai dengan yang pegawai harapkan, maka akan dapat memotivasi pegawai untuk meningkatkan kinerjanya.

Kompensasi juga merupakan penghargaan yang diberikan pegawai/karyawan baik langsung maupun tidak langsung, financial maupun non financial yang adil kepada karyawan atas sumbangan mereka dalam mencapai tujuan organisasi, sehingga pemberian kompensasi sangat dibutuhkan oleh perusahaan manapun guna meningkatkan kinerja pegawainya. Adapun bentuk kompensasi financial adalah gaji, tunjangan, bonus,dan komisi. Sedangkan untuk kompensasi nonfinancial diantaranya wewenang dan tanggung jawab, penghargaan atas kinerja.
Menurut
Handoko
(2001)

mengemukakan bahwa Kompensasi adalah

“ Segala sesuatu yang diterima para pegawai sebagai balas jasa untuk kerja mereka." Jadi untuk mendapatkan kompensasi yang sesuai dengan kinerja karyawan maka dibutuhkan pula pegawai yang memiliki potensi yang baik guna tercapainya tujuan bersama. Oleh karena itu di dalam sebuah kompensasi terdapat beberapa kompensasi berupa kompensasi financial yaitu insentif. Dalam pencapaian 
guna memenuhi kebutuhannya maka karyawan harus memiliki kinerja yang baik agar tercapainya tujuan bersama.

Berdasarkan fenomena di atas, maka penulis bermaksud melakukan penelitian secara lebih mendalam mengenai kompensasi terhadap kepuasan kerja yang dituangkan dalam skripsi yang berjudul: "Analisis Pengaruh Kompensasi Terhadap Kepuasan Kerja Pada CV. Setia Budi Di Bandar Lampung".

\section{KAJIAN TEORI}

\section{Pengertian Kompensasi}

Kompensasi merupakan salah faktor penting dan menjadi perhatian pada banyak organisasi dalam mempertahankan dan menarik sumber daya manusia yang berkualitas. Menurut I Komang Ardana (2012) "Kompensasi adalah segala sesuatu yang diterima oleh karyawan sebagai balas jasa atas kontribusinya kepada perusahaan atau organisasi”. Kompensasi dapat berupa gaji dan upah. Kompensasi bersifat financial dan non financial, sedangkan menurut Hasibuan (2012) "Kompensasi merupakan imbalan yang dibayarkan kepada karyawan atas jasa yang mereka sumbangkan pada pekerjaannya".

$$
\text { Menurut Hasibuan }
$$

"Kompensasi adalah semua pendapatan yang berbentuk uang, barang langsung atau tidak langsung yang diterima karyawan sebagai imbalan atas jasa yang diberikan kepada perusahaan". Menurut Hasibuan (2012) "Kompensasi merupakan salah satu faktor penting dan menjadi perhatian pada banyak organisasi dalam mempertahankan dan menarik sumberdaya manusia yang berkualitas".

\section{Pengertian Kepuasan kerja}

Setiap orang yang bekerja mengharapkan memperoleh kepuasan dari tempatnya bekerja. Pada dasarnya kepuasan kerja merupakan hal yang bersifat individual karena setiap individu akan memiliki tingkat kepuasan yang berbedabeda sesuai dengan nilai-nilai yang berlaku dalam diri setiap individu. Semakin banyak aspek dalam pekerjaan yang sesuai dengan keinginan individu, maka semakin tinggi tingkat kepuasan yang dirasakan.

Menurut Kreitner dan Kinicki dalam Hasibuan (2011) kepuasan kerja adalah "suatu efektifitas atau respons emosional terhadap berbagai aspek pekerjaan". Davis dan Newstrom dalam Susilo Martoyo (2013) mendeskripsikan "kepuasan kerja adalah seperangkat perasaan pegawai tentang menyenangkan atau tidaknya pekerjaan mereka".

Menurut Robbins dalam Sunyoto (2013) kepuasan kerja adalah "sikap umum terhadap pekerjaan seseorang yang menunjukkan perbedaan antara jumlah penghargaan yang diterima pekerja dan jumlah yang mereka yakini seharusnya mereka terima". Kepuasan kerja merupakan respon afektif atau emosional terhadap berbagai segi atau aspek pekerjaan seseorang sehingga kepuasan kerja bukan merupakan konsep tunggal. Seseorang dapat relatif puas dengan salah satu aspek pekerjaan dan tidak puas dengan satu atau lebih aspek lainnya.

Kepuasan Kerja merupakan sikap (positif) tenaga kerja terhadap pekerjaannya, yang timbul berdasarkan penilaian terhadap situasi kerja. Penilaian tersebut dapat dilakukan terhadap salah satu pekerjaannya, penilaian dilakukan sebagai rasa menghargai dalam mencapai salah satu nilai-nilai penting dalam pekerjaan. Karyawan yang puas lebih menyukai situasi kerjanya daripada tidak menyukainya. Perasaan-perasaan yang berhubungan dengan kepuasan dan ketidakpuasan kerja cenderung mencerminkan penaksiran dari tenaga kerja tentang pengalamanpengalaman kerja pada waktu sekarang dan 
lampau daripada harapan-harapan untuk masa depan. Sehingga dapat disimpulkan bahwa terdapat dua unsur penting dalam kepuasan kerja, yaitu nilai-nilai pekerjaan dan kebutuhan-kebutuhan dasar. Nilai-nilai pekerjaan merupakan tujuan-tujuan yang ingin dicapai dalam melakukan tugas pekerjaan. Yang ingin dicapai ialah nilainilai pekerjaan yang dianggap penting oleh individu.

Dikatakan selanjutnya bahwa nilai-nilai pekerjaan harus sesuai atau membantu pemenuhan kebutuhan-kebutuhan dasar. Dengan demikian dapat disimpulkan bahwa kepuasan kerja merupakan hasil dari tenaga kerja yang berkaitan dengan motivasi kerja. Kepuasan kerja secara keseluruhan bagi seorang individu adalah jumlah dari kepuasan kerja (dari setiap aspek pekerjaan) dikalikan dengan derajat pentingnya aspek pekerjaan bagi individu.

Seorang individu akan merasa puas atau tidak puas terhadap pekerjaannya merupakan sesuatu yang bersifat pribadi, yaitu tergantung bagaimana mempersepsikan adanya kesesuaian atau pertentangan antara keinginankeinginannya dengan hasil keluarannya (yang didapatnya). Sehingga dapat disimpulkan pengertian kepuasan kerja adalah sikap yang positif dari tenaga kerja meliputi perasaan dan tingkah laku terhadap pekerjaannya melalui penilaian salah satu pekerjaan sebagai rasa menghargai dalam mencapai salah satu nilai-nilai penting pekerjaan.

\section{Teori Kepuasan Kerja}

Teori kepuasan kerja mencoba mengungkapkan apa yang membuat sebagian orang lebih puas terhadap suatu pekerjaan daripada beberapa lainnya. Teori ini juga mencari landasan tentang proses perasaan orang terhadap kepuasan kerja. Ada beberapa teori tentang kepuasan kerja menurut Kreitner dan Kinicki (2011) yaitu

\section{Two Factor Theory}

Teori ini menganjurkan bahwa kepuasan dan ketidakpuasan merupakan bagian dari kelompok variabel yang berbeda yaitu motivators dan hygiene factors. Ketidakpuasan dihubungkan dengan kondisi disekitar pekerjaan (seperti kondisi kerja, upah, keamanan, kualitas pengawasan dan hubungan dengan orang lain) dan bukan dengan pekerjaan itu sendiri. Karena faktor mencegah reaksi negatif.

\section{Value Theory}

Menurut teori ini kepuasan kerja terjadi pada tingkatan dimana hasil pekerjaan diterima individu seperti diharapkan. Semakin banyak orang menerima hasil, akan semakin puas dan sebaliknya. Kunci menuju kepuasan pada teori ini adalah perbedaan antara aspek pekerjaan yang dimiliki dengan yang diinginkan seseorang. Semakiin besar perbedaan, semakin rendah kepuasan orang (Kreitner dan Kinicki dalam Hasibuan (2011).

\section{Faktor-faktor yang Mempengaruhi Kepuasan Kerja}

Ada 5 (lima) faktor yang dapat mempengaruhi kepuasan kerja menurut Kreitner dan Kinicki dalam Hasibuan (2011) yaitu sebagai berikut :

1. Pemenuhan kebutuhan (Need fulfillment) Kepuasan ditentukan oleh tingkatan karakteristik pekerjaan memberikan kesempatan pada individu untuk memenuhi kebutuhannya.

\section{Perbedaan (Discrepancies)}

Kepuasan merupakan suatu hasil memenuhi harapan. Pemenuhan harapan mencerminkan perbedaan antara apa yang diharapkan dan apa yang diperoleh 
individu dari pekerjaannya. Bila harapan lebih besar dari apa yang diterima, orang akan tidak puas. Sebaliknya individu akan puas bila menerima manfaat diatas harapan.

3. Pencapaian nilai (Value attainment) Kepuasan merupakan hasil dari persepsi pekerjaan memberikan pemenuhan nilai kerja individual yang penting.

4. Keadilan (Equity)

Kepuasan merupakan fungsi dari seberapa adil individu diperlakukan di tempat kerja.

5. Komponen

genetik

(Genetic components)

Kepuasan kerja merupakan fungsi sifat pribadi dan faktor genetik. Hal ini menyiratkan perbedaan sifat individu mempunyai arti penting untuk menjelaskan kepuasan kerja disampng karakteristik lingkungan pekerjaan.

\section{METODE PENELITIAN}

\section{Objek Penelitian}

Penelitian ini dilakukan pada CV. Setia Budi di Bandar Lampung, Perusahaan ini terletak di Jalan Pangeran Diponegoro Bandar Lampung. Penelitian dilaksanakan pada Bulan Maret 2019 sampai dengan bulan Juni 2019.

\section{Metode dan Teknik Pengumpulan Data}

Untuk mendapatkan dan mengumpulkan data yang sesuai dengan kebutuhan dalam penelitian ini, maka metode pengumpulan data yang digunakan adalah sebagai berikut :

1. Data primer yaitu jenis data yang dikumpulkan dan diolah langsung dari objek penelitian yaitu dari CV. Setia Budi Di Bandar Lampung.
2. Data Sekunder yaitu data yang bersumber dari luar objek penelitian seperti buku-buku, majalah, yang berkaitan dengan masalah penelitian ini.

Langkah-langkah pengumpulan data yang penulis lakukan dengan mengadakan penelitian lapangan yaitu : Penelitian yang dilakukan pada CV. Setia Budi, adapun teknik yang digunakan dalam pengumpulan data adalah dengan :

1. Observasi

Yaitu mengadakan survey atau pengamatan langsung ke lokasi penelitian.

2. Interview atau wawancara

Yaitu mengadakan tanya jawab langsung dengan karyawan CV. Setia Budi.

3. Dokumentasi

Yaitu mengumpulkan dan mencatat dokumentasi yang relevan.

4. Quisioner

Yaitu membuat pertanyaan yang berhubungan dengan varibael penelitian.

\section{Sampel dan Populasi}

Menurut Dr. Suharsimi Arikunto dalam bukunya prosedur Penelitian Suatu Pendekatan Praktek sebagai berikut apabila dalam suatu penelitian terhadap subjek yang kurang dari 100, maka sedangkan apabila subjek lebih dari 100 maka sampel yang diambil antara $10 \%-15 \%$ atau $20 \%, 25 \%$ atau lebih, dari seluruh populasi yang ada (Arikunto, 2010). Jumlah subjek dalam penelitian ini yang penulis ambil yaitu berjumlah 24 orang responden yang merupakan keseluruhan jumlah karyawan. 


\section{Metode Analisis Data}

Pendekatan dalam penelitian ini adalah pendekatan kuantitatif, karena penelitian ini disajikan dengan angka-angka. Hal ini sesuai dengan pendapat (Arikunto, 2010) yang mengemukakan penelitian kuantitatif adalah pendekatan penelitian yang banyak dituntut menguakan angka, mulai dari pengumpulan data, penafsiran terhadap data tersebut, serta penampilan hasilnya.

Persamaan Regresi Linear Sederhana menentukan persamaan regresi linear sederhana untuk $\mathrm{X}$ :

$$
Y=a+b X+e
$$

Keterangan:

$$
\begin{aligned}
& \mathrm{Y}=\text { Kepuasan kerja } \\
& \mathrm{a}=\text { Konstanta } \\
& \mathrm{b}=\text { Koefisien regresi } \mathrm{X} \\
& \mathrm{X}=\text { Kompensasi } \\
& \mathrm{e}=\text { Faktor kesalahan }
\end{aligned}
$$

Untuk mengetahui besarnya pengaruh, penghitungan koefisien korelasi tersebut kemudian dilanjutkan dengan Rumus Koefisien Determinasi atau Koefisien Penentu (KP):

$$
K P=(r)^{2} x 100 \%
$$

Untuk menguji secara hipotesis secara parsial digunakan Uji t dengan rumus :

$$
t_{\text {hitung }}=\frac{r \sqrt{N-2}}{\sqrt{1-r^{2}}}
$$

Keterangan:

$$
\begin{array}{ll}
\mathrm{t}_{\text {hitung }} & =\text { Nilai } \mathrm{t} \\
\mathrm{r} & =\text { Koefisien Korelasi } \\
\mathrm{N} & =\text { Jumlah responden }
\end{array}
$$
berikut :

Kriteria untuk Uji $t$ adalah sebagai

a) Jika $t_{\text {hitung }}>t_{\text {tabel }}$ maka Ha diterima dan Ho ditolak. b) Jika $t_{\text {hitung }} \leq t_{\text {tabel }}$ maka Ha ditolak dan Ho diterima.

\section{HASIL DAN PEMBAHASAN}

\section{Uji Validitas}

Uji validitas (kesesuaian) adalah sarana yang dipergunakan untuk mengetahui tingkat kesesuaian dari instrumen kuisioner yang dipergunakan dalam pengumpulan data. Uji validitas sebaliknya dilakukan pada setiap butir pertanyaan di uji validitasnya.

Selanjutnya untuk syarat minimum agar dianggap memenuhi syarat valid adalah dengan mengkorelasikan masingmasing dengan skor total variabel yang hasilnya akan dibandingkan dengan nilai $\mathrm{r}_{\text {tabel dimana taraf signifikansi yang }}$ digunakan adalah 0,05 atau 5\% dengan $\mathrm{n}=$ 40 dengan $d f($ degree of freedom $)=(\mathrm{N}-2)$ $=(40-2)=38$. Sehingga $r_{\text {tabel }}$ dalam penelitian ini yaitu sebesar : $\mathrm{r}(0,05 ; 38)=$ 0,2638 . Uji validitas dikatakan valid bila nilai $r_{\text {hitung }}$ lebih besar dari $r_{\text {tabel. }}$ Sebaliknya, uji validitas dikatakan tidak valid bila nilai $r_{\text {hitung }}$ lebih kecil dari $r_{\text {tabel }}$.

\section{Uji Reliabilitas Data}

Uji reliabilitas digunakan untuk mengukur suatu kuesioner yang merupakan indikator dari variabel. Untuk mengukur reliabilitas dengan menggunakan statistik Cronbach Alpha. Suatu variabel dikatakan reliabel jika memiliki Cronbach Alpha lebih dari 0,60. Dari hasil uji dapat diketahui bahwa masing-masing variabel memiliki Cronbach Alpha lebih dari 0,60 sehingga dapat disimpulkan bahwa semua variabel $\mathrm{X}$ (Insentif) dan Y (Disiplin Kerja) adalah reliabel.

\section{Analisis Kuantitatif}

Berdasarkan tabel diatas dapat dilihat persamaan regresi linier sederhana adalah Y 
$=8,905+0,283(\mathrm{X})$. Nilai konstanta yang diperoleh sebesar 8,905, hal ini berarti bahwa jika variabel independen (kompensasi) adalah bernilai nol, maka besarnya kepuasan kerja yang terjadi adalah 8,905 . Nilai koefisien regresi variabel kompensasi (X) sebesar 0,283, hal ini menunjukkan bahwa setiap kenaikan satu satuan modal akan mengakibatkan kenaikan kepuasan kerja sebesar 0,283.

Hasil pengujian koefisien determinasi menunjukkan bahwa nilai $R$ square sebesar 0.196. Nilai $R$ square ini menunjukkan bahwa besarnya kontribusi variabel independen terhadap variabel dependen adalah sebesar 19,6\%, sedangkan sisanya sebesar $80,4 \%$ ditentukan oleh variabel lain yang tidak teridentifikasi dalam penelitian ini. Dari hasil uji kelayakan dapat dilihat pada nilai signifikansi sebesar 0.03 lebih kecil dari 0.05. Dengan melihat tingkat signifikansi tersebut, maka model ini dapat digunakan untuk memprediksi kepuasan kerja (Y), dengan demikian persamaan model ini bersifat fit atau layak digunakan.

Pengujian untuk menjawab hipotesis yang menyatakan "Kompensasi berpengaruh terhadap kepuasan kerja." Pengujian dilakukan dengan menggunakan uji t yang menunjukkan bahwa Kompensasi berpengaruh terhadap kepuasan kerja. Pengujian dilakukan dengan menggunakan uji t pada tingkat keyakinan signifikansi $\alpha$ 0.05. Dari hasil tabel 4.8 dapat diketahui bahwa tingkat signifikansi sebesar 0.03 < 0.05 dengan nilai $t_{\text {hitung }}>t_{\text {tabel }}$ yaitu 2.314 $>$ 2.0686, dengan demikian hipotesis diterima yang berarti modal kompensasi berpengaruh terhadap kepuasan kerja.

\section{KESIMPULAN DAN SARAN}

\section{Kesimpulan}

Berdasarkan hasil penelitian dan pembahasan yang sudah dilakukan, maka hal yang dapat disimpulkan hasil pengujian bahwa nilai $R$ square sebesar 0.196 . Nilai $R$ square ini menunjukkan bahwa besarnya kontribusi variabel independen terhadap variabel dependen adalah sebesar 19,6\%. Nilai signifikansi sebesar 0.03 lebih kecil dari 0.05. Hipotesis yang menyatakan "Kompensasi berpengaruh terhadap kepuasan kerja." Pengujian dilakukan dengan menggunakan uji $t$ yang menunjukkan bahwa Kompensasi berpengaruh terhadap kepuasan kerja. Pengujian dilakukan dengan menggunakan uji t pada tingkat keyakinan signifikansi $\alpha$ 0.05. Dari hasil diketahui bahwa tingkat signifikansi sebesar $0.03<0.05$ dengan nilai $t_{\text {hitung }}>t_{\text {tabel }}$ yaitu $2.314>2.0686$, dengan demikian hipotesis diterima yang berarti modal kompensasi berpengaruh terhadap kepuasan kerja.

\section{Saran}

Berdasarkan hasil simpulan penelitian yang telah dijelaskan, maka beberapa hal yang bisa menjadi masukan bagi CV. Setia Budi antara lain:

1. CV. Setia Budi hendaknya mempertimbangan pemberian kompensasi dalam bentuk reward yang diberikan kepada pegawainya agar mereka semakin bersemangat untuk bekerja lebih baik.

2. CV. Setia Budi hendaknya memberikan tambahan insentif yang sesuai kepada prestasi kerja staf/pegawainya sehingga dapat bekerja dengan baik sesuai produktivitas dan semangat kerjanya.

3. CV. Setia Budi hendaknya memberikan rewand kepada pegawainya sesuai dengan kemampuan dan kualitas yang dimiliki sesuai dengan kinerjanya. 


\section{DAFTAR PUSTAKA}

Algifari, 2008: Metode Penelitian Bisnis. Cetakan Ke- 15. Bandung: CV. Alfabeta.

Arikunto, Suharsimi. 2010. Prosedur Penelitian Suatu Pendekatan Praktik. Edisi Revisi V. Jakarta: Rineka Cipta.

A J Kinicki, dkk dalam Hasibuan. 2010: Managemen Theory. Edisi 9. Jakarta: Salemba Empat.

Budiyono. 2012. Manajemen Sumber Daya Mansia. Jakarta: Erlangga.

Daft, Ferdinand. 2006. Manajemen Sumber Daya Manusia. Jakarta: Elex Media Kompetindo.

Hasibuan. 2012. Organisasi dan Motivasi. Jakarta: PT. Bumi Aksara.

Jatmiko. 2004. Manajemen Stratejik. Malang: UMM Press.

Husein Umar dalam Sunyoto. 2012. Manajemen Sumber Daya Manusia Strategik. Jakarta: Ghalia Indonesia.

Mangkunegara, Prabu AA Anwar. 2014. Sumber Daya Manusia. Jakarta: Salemba empat.

Priyatno. 2008. Metode Penelitian Bisnis, Cetakan Ke- 15. Bandung: CV. Alfabeta.

Robbins (dalam Sunyoto). 2013. Organization Management. Alih bahasa. Djoerban Wahid. Jakarta: Penerbit Erlangga.

Soeratno (dalam Purnamasari). 2008. Psikologi Islami: Seri Sumber Daya Manusia. Yogjakarta: Liberty.
Sugiyono. 2010. Metode Penelitian Bisnis. Cetakan Ke- 15. Bandung: CV. Alfabeta.

Susilo, Martoyo .2012. Perilaku, Struktur dan Prosesi. Alih bahasa. Jakarta: Erlangga.

Wibowo. 2012. Manajemen Personalia dan Sumber Daya Manusia. Yogjakarta: BPFE Press. 